\title{
Design of Miniature Complex Loop Input/Output Simulator for Fuel Gas and Seal Gas Filter Separators by using Distributed Control System
}

\author{
Fitria Hidayanti ${ }^{1}$, Hari Hadi Santoso ${ }^{2}$, Erna Kusuma Wati ${ }^{2}$, Gagah Gigih Prasetyo $^{2}$ \\ ${ }^{1}$ Engineering Physics Department, Universitas Nasional, Jakarta 12520 Indonesia, fitriahidayanti@gmail.com \\ ${ }^{2}$ Engineering Physics Department, Universitas Nasional, Jakarta 12520 Indonesia
}

\begin{abstract}
In the industry, the Distributed Control System (DCS) development project as a process control system is always carried out by Factory Acceptance Test (FAT) as a technical evidence that the Distributed Control System has been made to meet the approved specifications before being shipped to the plant. In FAT activities, testing of configurations that have been made on the DCS controller must be conducted. Due to conventional ways have limited measurement tools, it will be difficult to do the actual input/output (I/O) loop check. This activity takes a long time and it was not efficient. Therefore, the design of miniature complex loop input/output simulator for fuel gas and seal gas filter separators by using distributed control system was crucial and process simulation in factory acceptance test was conducted to be more effective and efficient.
\end{abstract}

Key words : Complex Loop, Process Control System, Distributed Control System, Factory Acceptance Test, I/O Simulator

\section{INTRODUCTION}

Distributed control system (DCS) [1-3] are used in industries to monitor and control equipment that is dispersed with or without human intervention. A DCS typically use a computer as a controller and use proprietary interconnections and protocols for communication. The input and output modules form a component part for DCS, the processor receives information from the input module and sends the information to the output module. They also connect the controllers that are dispersed to the central controller and eventually connect to the Human Machine Interface (HMI) or Control Panel [4-6].

In the distributed control system development project, the Factory Acceptance Test (FAT) [7-9] is always carried out in the engineering company, as the technical evidence that the Distributed Control System has been made to meet the agreed specifications, before being sent to the field. In FAT activities, the configurations that have been made on the DCS Controller will be tested. One of them is the configuration for doing I/O (input/output) loop check [10-12]. Currently testing the loop check process is still done manually. Internal simulation test I/O (input/output). The loop check that is done by manual has a lot of shortcomings, including the difficulty of doing a complex loop check where to in the internal test loop complex I/O (input / output) the loop check requires several measuring instruments components. Due to the limitation of measuring instruments, it will be difficult to perform actual simulation I/O loop check, this activity takes a long time, so it is inefficient. In addition to this simulation activity is not effective because it is done bypass in the system or will not require a lot of measuring equipment, which will certainly be difficult to understand by the customer. Therefore, in this research need to design miniature input/output simulators given the importance of truth and accuracy of configuration, Value, Graphic Display in Distributed Control System when the activity of the Factory Acceptance Test. If there is an error in the configuration, where the codified will be applied to the actual Field Instrument, it is certainly very feared will cause various problems in the field.

\section{MATERIALS AND METHODS}

Fuel dan Seal Gas Separators - Auto Switching pada DCS

This study designed I/O fuel simulator and gas seal separators - auto-switching that will be implemented on DCS where this complex loop simulates the process control for two fuel and a gas seal filter separator (60MAJ-101A/B) in a parallel configuration is provided. The purpose of this controller is to auto-switch streams from online separator filter to stand-by filter separator by opening/closing 2 inlet valves (XV-001A and $\mathrm{XV}-001 \mathrm{~B}$ ) in high-level cases (LAH-001A/B) or high differential pressure (PDAH-001A/B) detected in filters online. Valves can be unlocked with SOV001A energy for XV-001A and SOV001B for XV-001B of DCS. The auto-switch controller for the filter separator gets input.

- When reaching a high level, the filter separator (LAH-001A/LAH001B) and high-pressure differential filter separator (PDAH-001A/ 
PDAH-001B) were only one selected in the soft tag graphic (SS-001B/SS-001A).

- Hand switch (HS-001A/HS-001B) is provided on the DCS manual, select a filter to work if all the conditions in both filters are met when working manually.

\section{Working Principle I/O Simulator on DCS}

Simulate instrument attached with tested measuring instruments of measurement results (Table 1 - Table 2).

- High-level filter separator (potentiometer-2A/B) and high-pressure differential filter separator (potentiometer-3A/B) are only one selected by the controller selector (Toggle_Switch-2A/B).

- Hand switch (Toggle_Switch-3A/B) is provided on the DCS manual [13, 14], select which filter for duty if all the conditions in both filters are met according to the stage in the filtering process. Microcontroller will provide inputs to the DCS I/O card, which is the reference for calculation and control process auto-switching filtering.

Table 1: Table Chart Shutdown Valve on Human Machine Interface

\begin{tabular}{|c|c|c|c|c|}
\hline $\begin{array}{c}\text { ZSO } \\
\text { Status }\end{array}$ & $\begin{array}{c}\text { ZSC } \\
\text { Status }\end{array}$ & $\begin{array}{c}\text { Solenoid } \\
\text { Command }\end{array}$ & $\begin{array}{c}\text { Valve } \\
\text { Colour }\end{array}$ & $\begin{array}{c}\text { Valve } \\
\text { Status }\end{array}$ \\
\hline 1 & 0 & 1 & yellow & $\begin{array}{c}\text { Valve } \\
\text { fully } \\
\text { opened }\end{array}$ \\
\hline 0 & 1 & 0 & white & $\begin{array}{c}\text { Valve } \\
\text { fully } \\
\text { closed }\end{array}$ \\
\hline
\end{tabular}

Table 2: Table Chart Blowdown on Human Machine Interface

\begin{tabular}{|c|c|c|c|c|}
\hline $\begin{array}{c}\text { ZSO } \\
\text { Status }\end{array}$ & $\begin{array}{c}\text { ZSC } \\
\text { Status }\end{array}$ & $\begin{array}{c}\text { Solenoid } \\
\text { Command }\end{array}$ & $\begin{array}{c}\text { Valve } \\
\text { Colour }\end{array}$ & $\begin{array}{c}\text { Valve } \\
\text { Status }\end{array}$ \\
\hline 1 & 0 & 0 & white & $\begin{array}{c}\text { Valve } \\
\text { fully } \\
\text { opened }\end{array}$ \\
\hline 0 & 1 & 1 & yellow & $\begin{array}{c}\text { Valve } \\
\text { fully } \\
\text { closed }\end{array}$ \\
\hline
\end{tabular}

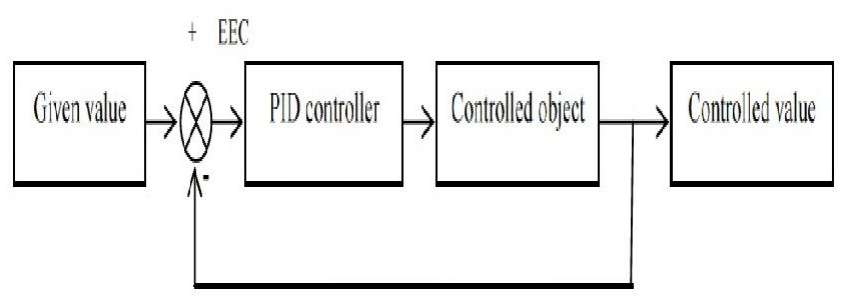

Figure 1: Block Diagram on Fuel Gas and Seal Gas Filter Separators System

\section{Hardware Design}

This study made a simulator to simulate complex loop when performing the proving process. The simulator comes with an indicator light that makes the simulation activity clearly visible. The simulators integrate with DCS to simulate proving processes controlled and calculated by DCS (Figure $1)$.

\section{Complex Loop I/O Simulator Display Design}

To make the simulator easy to understand and interactive, it certainly needs to be designed the front-end simulators that correspond to the actual conditions in the field. The complex loop simulator view is as follows (Figure 2).

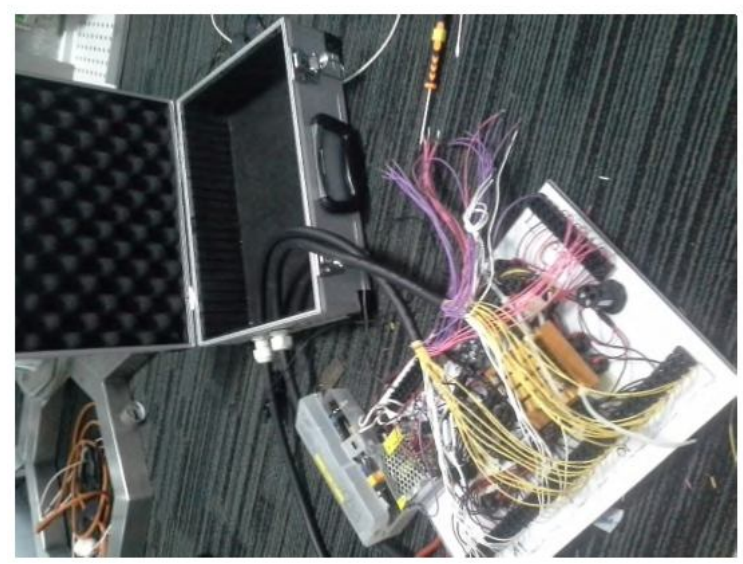

Figure 2: Complex Loop I/O Simulator

\section{Wiring Diagram Simulator Design}

After the hardware design of complex loop simulator then it can start designed wiring diagrams of complex loop simulator. Wiring diagram simulator consists of 3 images, namely Power Distribution Diagram, Digital Input Wiring Diagram, and Digital Output Wiring Diagram.

Power distribution is used to turn on the complex loop simulator where the voltage input is 24 VDC, the 24 VDC voltage is a supply for the DCS Controller, the output of the relay run command and the indicator light. 5 VDC power supply is used to light the microcontroller.

\section{Wiring DCS Design}

After designing the Wiring Diagram Simulator, it began to be designed Wiring Diagram DCS towards Complex Loop Simulator. The DCS wiring Diagram consists of 2 images, 
namely the Wiring Diagram Pulse Input DCS and Switch Wiring Diagram DCS.

The function of wiring diagrams pulses of DCS as input for flow rate, while the function switches wiring diagram DCS to simulate fuel process and gas seal separators - auto-switching.

\section{Programming on DCS}

- Graphic Display. Figure 3 showed a result of a configuration that will represent the actual process condition of Fuel Gas and Seal Gas Filter Separators.

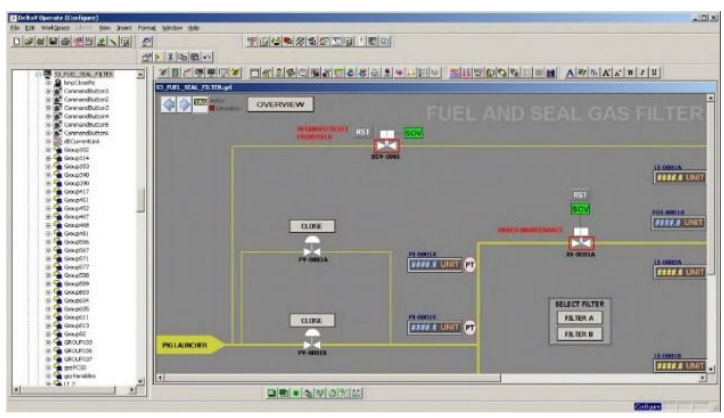

Figure 3: Display Configuration

- Module and Database (Figure 4)

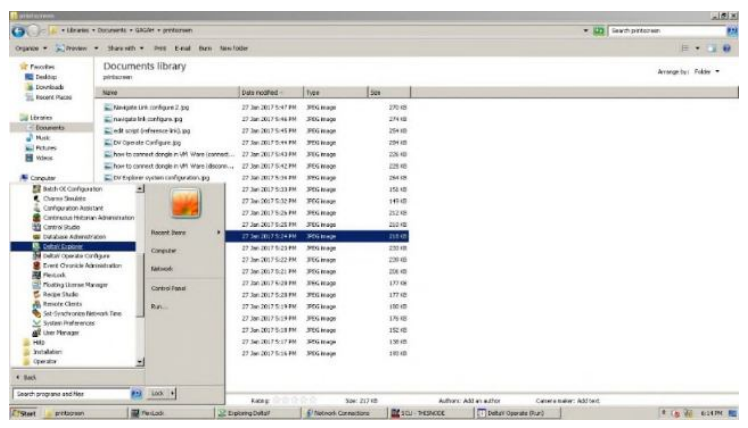

Figure 4: Configuration of I/O Database

- Logic Diagram (Figure 5)

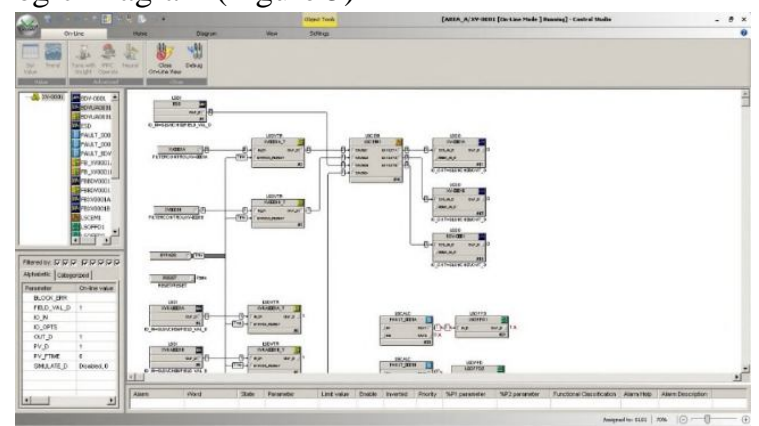

Figure 5: Configuration of Logic Diagram

\section{Programming on microcontrollers}

In the design of this simulator (Figure 6), the microcontroller used is the Arduino Mega model 2560. Software 1.6.8 is used to create the program.
This programming generates a digital signal output with a microcontroller with hardware to become digital input on DCS in this $\mathrm{I} / \mathrm{O}$ simulator module.

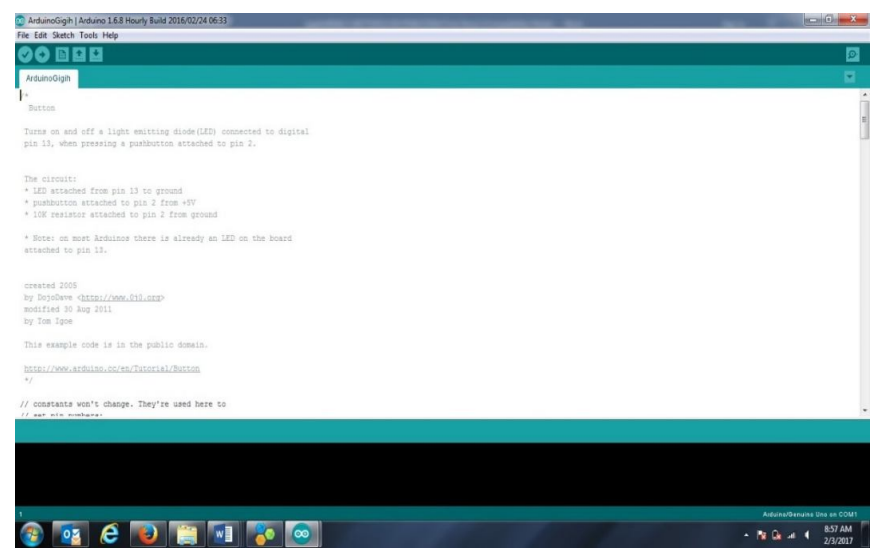

Figure 6: Configuration of Microcontroller

\section{RESULTS AND DISCUSSION}

Tool testing was done by integrating I/O complex loop simulator with all the installed DCS hardware and has been wiring done. The simulator shows the hardware and programs designed to function properly.

\section{Hardware components and programmatically run on DCS}

- The signal cables, power and communication cables have been successfully integrated between DCS, microcontroller and I/O simulator (Figure 7).

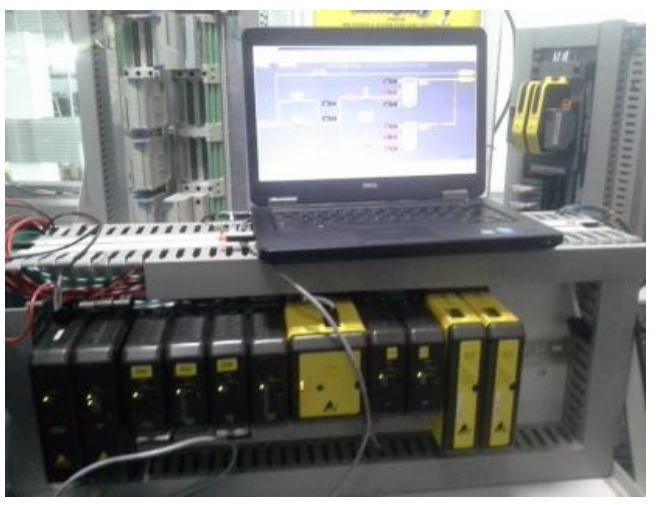

Figure 7: DCS integrated with hardware

- Delta V Explorer display integrated with DCS hardware, microcontroller and I/O simulator (Figure 8). 


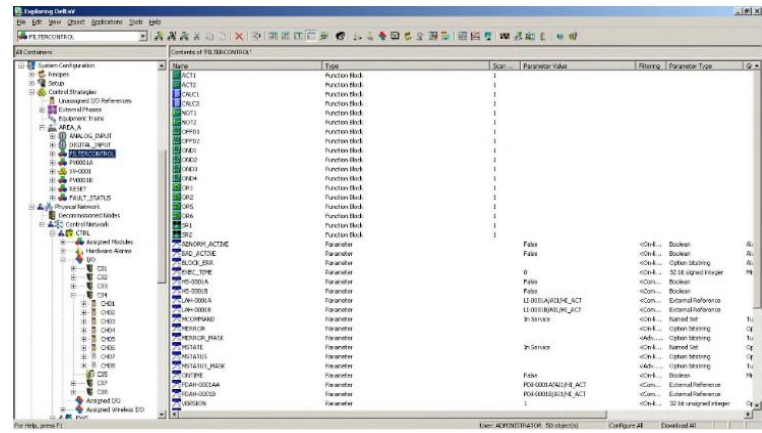

Figure 8: Delta V configuration

- The "Delta V operate Run" view when the program is run. Delta V operate run already executed. This view is used as condition field when the plant is already in commissioning (Figure 9).

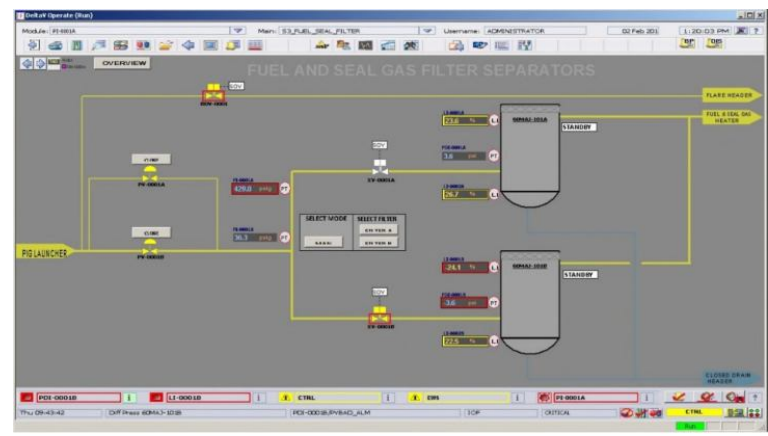

Figure 9: Delta V Operate Run

- The overall status of system integrity will be seen in system diagnostic. The diagnostic system is used to view the condition or status of the DCS through. Then install the license ID on the available dongle. Download it to the folder controllers and EWS. Make sure the controller is active (commissioning).

- The "studio control" view is already executed which serves to ensure that the control logic is configured according to the needs of the narrative control (Figure $10)$.

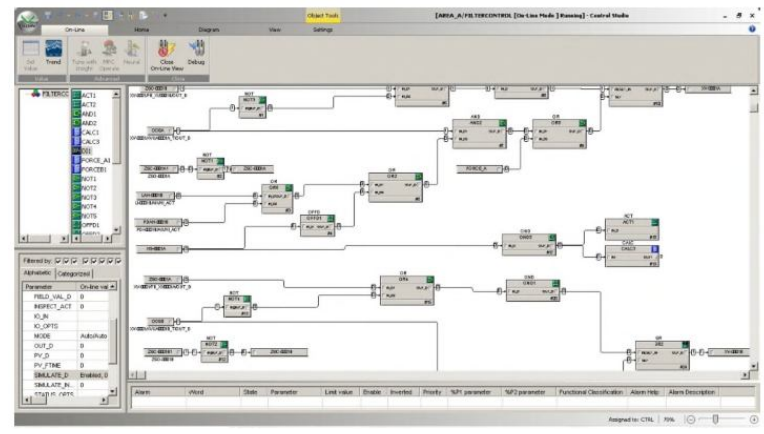

Figure 10: The block function configuration

The DCS software and hardware display, microcontroller and I/O Simulator are well connected and can be seen in the diagnostic system.
a. Controller
b. I/O Module
c. DCS Control Network
d. Field Instrument (I/O Simulator)
e. Human Machine Interface (Engineering workstation)

\section{Loop Check}

Once the diagnostic system has been shown, the DCS already display the overall integrity in good condition then can be checked loop each channel in module I/O card.

- Digital input loop checking. After the experiment was conducted, toggle position switches moved to the top "ON" SS001A/B, visible on the card 32 channel Card-03 channel 03 Get the signal shifting from "0" to "1". Toggle position switches down "OFF" SS001A/B. The signal is changed back from "1" to "0".

- Digital output loop checking. Once the experiment was made, "force input from" 0 "to" 1 "a 24VDC indication light on the simulator illuminates. When disabled force input to "0". 24VDC indication Light will return at the "off" position.

- Analog Input Loop checking. In this experiment set Potentiometer to emit value of $15.89 \mathrm{~mA}$, in diagnostic system visible status on analog input card displays the value "74.88\%". And on the faceplate icon "LI" in the circle, shows the value "74.88\%".

From the above experiments can be concluded that as a tool that will simulate the condition of the limit switches simulated with toggle switch, lamp 24VDC as the condition of SOV, and the transmitter either pressure, temperature, level or flow in the field as analog input is already working as desired.

\section{Function Test}

Here are the results of experiments that have been done from the function test on the Fuel and Seal gas Filter Separators-Auto-Switching System.

- Step-1 experiment. The ESD "Emergency Shutdown" button is pressed, the output becomes XV0001 A\&B, PV-0001 A\&B and BDV-0001 change its status to "Off". After that the limit switch gives feedback Valve is open/closed fully.

- Step-2 experiment. When moved the position of "maintenance mode" Toggle switch XV0001 A\&B in "on" position. See the graphic display, seen in the "Maintenance mode" on the line XV-0001 A\&B.

- Step-3 experiment. The "Emergency Shutdown" ESD button was released, so the PV-0001 A\&B and BDV-0001 changed its status to "On". After that the limit switch gives feedback to inform that the valve is open/closed fully.

- Step-4 experiment. The "Maintenance Mode" Toggle switches the XV-0001 A\&B position on the "Off" position. Seen in graphic view, the "Maintenance mode" on the line XV-0001 A\&B disappeared. In Graphic view appear the mode selection box "Manual" and "Auto". 
- Step-5 experiment. See the Toggle position of switches on filter selector. And the position is already on "Filter A".

- Step-6 experiment. When done click on selection mode in "Manual" mode. XV0001A ON or "ON". And moved toggle position switch Feedback $\mathrm{XV}-0001 \mathrm{~A}$ to "ON", the Active lamp will be "ON" and the standby lamp is off "Off".

- Step-7 experiment. The pressure value of PDI-0001 A is simulated on line filter A "PDI0001A" and the level on Separator A "LI-0001A" becomes above > $75 \%$. Solenoid XV-0001B would be "ON", and moved the position of the feedback XV0001B the light to "active" on XV-0001B. Delay of 7 seconds, solenoid valve on XV-0001A "Off".

- Step-8 experiment. Simulate pressure value on line filter A "PDI-0001A and the level on Separator A" LI-0001A "to $25 \%$. The XV-0001A will be active or "ON". Move toggle position switch feedback to XV0001A to "ON", then the Active light will "ON" and the Standby Lamp will die "Off".

- Step-9 experiment. When, it is moved to the "Filter B" position. Solenoid XV-0001B n "ON", XV-0001B feedback position transferred "active" to $\mathrm{XV}-0001 \mathrm{~B}$. Delay of 7 seconds, solenoid valve on XV-0001A "Off".

- Step-10 experiment. Mode selection in "Auto" mode. Filter A, XV-0001 A active or "ON". Toggle Position switch Feedback for the XV-0001A was moved to "ON", the Active lamp "ON" and the standby lamp is off "Off".

- Step-11 experiment. The pressure value on line filter A "PDI-0001A and the level on separator A" LI-0001A "is simulated to above > 75\%. Solenoid XV0001B "ON", after moving the position of the feedback XV-0001B lamp "active" on XV-0001B. Delay for 7 seconds, automatically solenoid valve on XV-0001A die "Off".

- Step-12 experiment. "LI-0001A ' is returned to $25 \%$.

- Step-13 experiment. After the pressure value in line filter B "PDI-0001A and the level on Separator B" LI-0001A "simulated above > 75\%. Solenoid $\mathrm{XV}-0001 \mathrm{~B}$ to "ON", when moving the feedback position XV-0001A lamp "active" on XV-0001A. Delay for 7 seconds, automatically solenoid valve on XV-0001B to "OFF".

- Step-14 experiment. After Filter B in the click, XV-0001B becomes active or "ON". Toggle Position switch Feedback for XV-0001B transferred to "ON", Active lamp becomes "ON" and Standby lamp is off "Off". Delay for 7 seconds, automatically solenoid valve on XV-0001A to "OFF".

- Step-15 experiment. After the pressure value on line PV-0001 A\&B simulated to above $>75 \%$. The Valve controls on the PV-0001A are "off" and cannot be operated through the HMI.

- Step-16 experiment. The pressure value on the PV-0001 A\&B line is simulated back to $30 \%$. The
Valve control on the PV-0001A becomes "On" and can be re-operated through the HMI.

- Step-17 experiment. Step-16 experiment. After pressing Emergency Shutdown Push Button, XV-0001 A\&B, PV-0001 A\&B and BDV become "OFF" followed by indication of feedback in each valve.

From the analysis results, this I/O Simulator has been successfully integrated with Distributed Control Systems hardware with real-time conditions, pressures, and levels can be displayed on Graphic at Human Machine Interface. The test result of Loop checking is appropriate. This working principle of I/O Simulator is already able to run accordingly. Therefore, I/O Simulator can be implemented to perform simulations proving when factory acceptance test is performed.

Accuracy of I/O Simulator readings is calculated based on tolerance value and error value in calculations (Table 3 Table 5).

Table 3: Calculation of the I/O simulator results on loop checking

\begin{tabular}{|c|c|c|c|c|c|}
\hline \multicolumn{2}{|c|}{ Field Instrument } & \multirow{2}{*}{$\begin{array}{c}\text { IO } \\
\text { Simulator } \\
\begin{array}{c}\text { Resistant } \\
\text { (ohm) }\end{array}\end{array}$} & \multicolumn{2}{|c|}{ DCS IO Module } & \multirow{2}{*}{$\begin{array}{l}\text { DCS } \\
\text { HMI } \\
(\%)\end{array}$} \\
\hline $\begin{array}{c}\text { Field } \\
\text { Instrument }\end{array}$ & $\begin{array}{l}\text { Pressure } \\
\text { (psi) }\end{array}$ & & $\begin{array}{c}\text { Signal } \\
\text { Type }\end{array}$ & $\begin{array}{c}\text { Current } \\
(\mathrm{mA})\end{array}$ & \\
\hline $\begin{array}{c}\text { Level } \\
\text { Transmitter }\end{array}$ & 0.0012 & 5970 & $\begin{array}{c}\text { Analog } \\
\text { Input } \\
\text { 4-20mA }\end{array}$ & 4.02 & 0.01 \\
\hline $\begin{array}{c}\text { Level } \\
\text { Transmitter }\end{array}$ & 3.00168 & 2980 & $\begin{array}{c}\text { Analog } \\
\text { Input } \\
\text { 4-20mA }\end{array}$ & 8.02 & 25.01 \\
\hline $\begin{array}{c}\text { Level } \\
\text { Transmitter }\end{array}$ & 6.012 & 1980 & $\begin{array}{c}\text { Analog } \\
\text { Input } \\
\text { 4-20mA }\end{array}$ & 12.12 & 50.1 \\
\hline $\begin{array}{c}\text { Level } \\
\text { Transmitter }\end{array}$ & 9.036 & 1480 & $\begin{array}{c}\text { Analog } \\
\text { Input } \\
4-20 \mathrm{~mA}\end{array}$ & 16.21 & 75.3 \\
\hline $\begin{array}{c}\text { Level } \\
\text { Transmitter }\end{array}$ & 12.024 & 1180 & $\begin{array}{c}\text { Analog } \\
\text { Input } \\
4-20 \mathrm{~mA}\end{array}$ & 20.33 & 100 \\
\hline
\end{tabular}

Table 4: The first test result of the output value of I/O simulator on DCS hardware

\begin{tabular}{|c|c|c|c|c|c|}
\hline \multicolumn{2}{|c|}{ Field Instrument } & $\begin{array}{c}\text { IO } \\
\text { Simulator }\end{array}$ & \multicolumn{2}{c|}{ DCS IO Module } & $\begin{array}{c}\text { DCS } \\
\text { HMI }\end{array}$ \\
\hline $\begin{array}{c}\text { Field } \\
\text { Instrument }\end{array}$ & $\begin{array}{c}\text { Pressure } \\
(\mathrm{psi})\end{array}$ & $\begin{array}{c}\text { Resistant } \\
(\mathrm{ohm})\end{array}$ & $\begin{array}{c}\text { Signal } \\
\text { Type }\end{array}$ & $\begin{array}{c}\text { Current } \\
(\mathrm{mA})\end{array}$ & $(\%)$ \\
\hline $\begin{array}{c}\text { Level } \\
\text { Transmitter }\end{array}$ & 0.012 & 5970 & $\begin{array}{c}\text { Analog } \\
\text { Input } \\
\text { 4-20mA }\end{array}$ & 3.6 & 0.1 \\
\hline $\begin{array}{c}\text { Level } \\
\text { Transmitter }\end{array}$ & 2.5644 & 2980 & $\begin{array}{c}\text { Analog } \\
\text { Input } \\
4-20 \mathrm{~mA}\end{array}$ & 6.7 & 21.37 \\
\hline $\begin{array}{c}\text { Level } \\
\text { Transmitter }\end{array}$ & 5.3568 & 1980 & $\begin{array}{c}\text { Analog } \\
\text { Input }\end{array}$ & 9.7 & 44.64 \\
\hline
\end{tabular}


Fitria Hidayanti et al., International Journal of Emerging Trends in Engineering Research, 8(7), July 2020, 3122 - 3128

\begin{tabular}{|c|c|c|c|c|c|}
\hline & & & $4-20 \mathrm{~mA}$ & & \\
\hline $\begin{array}{c}\text { Level } \\
\text { Transmitter }\end{array}$ & 6.1452 & 1480 & $\begin{array}{c}\text { Analog } \\
\text { Input } \\
4-20 \mathrm{~mA}\end{array}$ & 12.5 & 51.21 \\
\hline $\begin{array}{c}\text { Level } \\
\text { Transmitter }\end{array}$ & 1.8132 & 1180 & $\begin{array}{c}\text { Analog } \\
\text { Input } \\
4-20 \mathrm{~mA}\end{array}$ & 14.9 & 15.11 \\
\hline
\end{tabular}

Table 5: The second test result of the output value of I/O simulator on DCS hardware

\begin{tabular}{|c|c|c|c|c|c|}
\hline \multicolumn{2}{|c|}{ Field Instrument } & \multirow{2}{*}{$\begin{array}{c}\text { IO } \\
\text { Simulator } \\
\begin{array}{c}\text { Resistant } \\
\text { (ohm) }\end{array}\end{array}$} & \multicolumn{2}{|c|}{ DCS IO Module } & \multirow{2}{*}{$\begin{array}{c}\text { DCS } \\
\text { HMI } \\
(\%)\end{array}$} \\
\hline $\begin{array}{c}\text { Field } \\
\text { Instrument }\end{array}$ & $\begin{array}{l}\text { Pressure } \\
\text { (psi) }\end{array}$ & & $\begin{array}{l}\text { Signal } \\
\text { Type }\end{array}$ & $\begin{array}{c}\text { Current } \\
(\mathrm{mA})\end{array}$ & \\
\hline $\begin{array}{c}\text { Level } \\
\text { Transmitter }\end{array}$ & 0.0012 & 5600 & $\begin{array}{c}\text { Analog } \\
\text { Input } \\
4-20 \mathrm{~mA}\end{array}$ & 3.8 & 0.01 \\
\hline $\begin{array}{c}\text { Level } \\
\text { Transmitter }\end{array}$ & 3.00168 & 2700 & $\begin{array}{c}\text { Analog } \\
\text { Input } \\
4-20 \mathrm{~mA}\end{array}$ & 7.5 & 25.01 \\
\hline $\begin{array}{c}\text { Level } \\
\text { Transmitter }\end{array}$ & 6.012 & 1500 & $\begin{array}{c}\text { Analog } \\
\text { Input } \\
4-20 \mathrm{~mA}\end{array}$ & 12.3 & 50.1 \\
\hline $\begin{array}{c}\text { Level } \\
\text { Transmitter }\end{array}$ & 9.036 & 1000 & $\begin{array}{c}\text { Analog } \\
\text { Input } \\
4-20 \mathrm{~mA}\end{array}$ & 16.21 & 75.3 \\
\hline $\begin{array}{c}\text { Level } \\
\text { Transmitter }\end{array}$ & 12.024 & 820 & $\begin{array}{c}\text { Analog } \\
\text { Input } \\
4-20 \mathrm{~mA}\end{array}$ & 20.2 & 100 \\
\hline
\end{tabular}

From the data obtained, I/O simulator can represent the value of the field instrument. When compared to the control narrative, the function test steps with the test results can be analyzed that I/O simulator can represent the field instrument or actual condition in the field. With the condition of signal issued by the used field instrument followed by the type I/O simulator signal to be designed.

\section{CONCLUSION}

The simulators created have the ability to simulate a loop check with the analog result of a 4-20mA signal or a value of $0 \%-100 \%$. Digital input (digital dry contact signal) and digital output (24 VDC active) in the function test process with a tolerance limit not exceeding $0.15 \%$ visible on the Distributed Control System (DCS) diagnostics and calculation results appearing on the faceplate and graphic display. With the benefit of I/O Simulator for simulating the Loop Test control, the required values according to what is obtained and can prove that the I/O Simulator configuration for complex loop, fuel and gas seal separators filter process, auto-switching is already running according to flow diagram and narrative control with good results and according to the specified standards. The simulators that are built can be integrated with the Distributed Control System (DCS) and the test process I/O simulation is very interactive and efficient.

\section{ACKNOWLEDGEMENT}

Thank you for Lembaga Penelitian dan Pengabdian kepada Masyarakat (LPPM) Universitas Nasioal and my colleagues at Faculty of Engineering and Science, Universitas Nasional, Jakarta, Indonesia.

\section{REFERENCES}

1. Poudel, B. P., Mustafa, A., Bidram, A., and Modares, H. Detection and mitigation of cyber-threats in the DC microgrid distributed control system. International Journal of Electrical Power \& Energy Systems, 120, 105968. 2020.

https://doi.org/10.1016/j.ijepes.2020.105968

2. Chen, R., Liu, B., Pan, M., and Zhou, H. Design of Distributed Control System for the Pick-up Robot Based on CAN Bus. In 2019 IEEE International Conference on Mechatronics and Automation (ICMA) (pp. 102-107). IEEE. August, 2019.

3. Hidayanti F., Santoso H. H., and Amalia D. Induction Measurement of Extra High Voltage Air Duct. International Journal of Emerging Trends in Engineering Research. 8(4), 1424 - 1427. 2020. https://doi.org/10.30534/ijeter/2020/78842020

4. He, Q., Wu, Y., Feng, Z., Sun, C., Fan, W., Zhou, Z., ... and Yang, J. Triboelectric vibration sensor for a human-machine interface built on ubiquitous surfaces. Nano Energy, 59, 689-696. 2019. https://doi.org/10.1016/j.nanoen.2019.03.005

5. Mahmud, S., Lin, X., and Kim, J. H. Interface for Human Machine Interaction for assistant devices: a review. In 2020 10th Annual Computing and Communication Workshop and Conference (CCWC) (pp. 0768-0773). IEEE. January 2020.

6. Hidayanti F., Rahmah F., and Sahro A. Mockup as Internet of Things Application for Hydroponics Plant Monitoring System. International Journal of Advanced Science and Technology. 29(05), 5157 - 5164. 2020.

7. Li, G., Dong, Y., Tian, J., Wang, W., Li, W., and Belanger, J. Factory acceptance test of a five-terminal MMC control and protection system using hardware-in-the-loop method. In 2015 IEEE Power \& Energy Society General Meeting (pp. 1-5). IEEE. July 2015.

8. Ding, K., Zhou, T., Lu, K., Du, Q., Li, B., Yu, S., ... and Ran, Q. Factory acceptance test of 50-ka hts current leads for the iter cs magnet test application. IEEE Transactions on Applied Superconductivity, 28(3), 1-4. 2017. https://doi.org/10.1109/TASC.2017.2783881

9. Hidayanti F., Rahmah F., and Wiryawan A. Design of Motorcycle Security System with Fingerprint Sensor using Arduino Uno Microcontroller. International Journal of Advanced Science and Technology. 29(05), 4374 - 4391. 2020. 
Fitria Hidayanti et al., International Journal of Emerging Trends in Engineering Research, 8(7), July 2020, 3122 - 3128

10. Goudarzian, A., Khosravi, A., and Abjadi, N. R. Input-output current regulation of Zeta converter using an optimized dual-loop current controller. Electrical Engineering, 1-13. 2019.

11. Zheng, Y., Furieri, L., Papachristodoulou, A., Li, N., and Kamgarpour, M. On the equivalence of Youla, System-level and Input-output parameterizations. IEEE Transactions on Automatic Control. 2020.

https://doi.org/10.1109/TAC.2020.2979785

12. Hidayanti F., Wati E.K., and Miftahudin M. F. Design of Energy Harvesters on Motorcycle Exhaust using Thermoelectric Generator for Power Supply Electronic Device. International Journal of Renewable Energy Research. 10(1), 251 - 259. 2020.

13. Yang, Z. H., Ma, Q., Liu, M. M., Zhang, Z. P., and Wang, K. Research and Analysis on 1E Distributed Control System Priority Logic Module. In International Symposium on Software Reliability, Industrial Safety, Cyber Security and Physical Protection for Nuclear Power Plant (pp. 415-429). Springer, Singapore. August 2019. https://doi.org/10.1007/978-981-15-1876-8_42

14. Hidayanti F., Lestari K. R., and Anwar R. Arduino Based Conductive Silver Lamination Device. International Journal of Emerging Trends in Engineering Research. 8(2), 265 - 270. 2020.

https://doi.org/10.30534/ijeter/2020/04822020 